\title{
EXPOSURE TO TICKS AND PREVENTIVE ACTIONS IN THE SCOPE OF LYME DISEASE AMONG YOUNG PEOPLE FROM THE NORTHERN PART OF LUBLIN PROVINCE (EASTERN POLAND)
}

\section{EKSPOZYCJA NA KLESZCZE ORAZ PODEJMOWANIE DZIAŁAŃ W ZAKRESIE PROFILAKTYKI BORELIOZY Z LYME WŚRÓD MŁODZIEŻY Z PÓŁNOCNEJ LUBELSZCZYZNY (WSCHODNIA POLSKA)}

\author{
Anna Pańczuk ${ }^{1(A, B, C, D, E, F)}$, Maria Kozioł-Montewka ${ }^{1(A, D, E)}$
}

${ }^{1}$ Pope John Paul II State School of Higher Education in Biała Podlaska, Poland

Authors' contribution Wkład autorów:

A. Study design/planning zaplanowanie badań B. Data collection/entry zebranie danych C. Data analysis/statistics dane - analiza i statystyki D. Data interpretation interpretacja danych E. Preparation of manuscript przygotowanie artykułu F. Literature analysis/search wyszukiwanie i analiza literatury G. Funds collection zebranie funduszy
Tables: 0

Figures: 6

References: 28

Submitted: 2016 Aug 15

Accepted: 2016 Sep 15

\section{Summary}

Background. The ticks are the main vector of pathogens of infectious diseases both for people and animals. At present, tick-borne infections spread in the entire Europe. Lyme disease dominates among diseases spreading through ticks. The aim of the research was to determine the frequency of exposures to ticks of the subjected young people, applied ways of removing the ticks and the frequency of using the selected methods of Lyme disease prevention.

Material and methods. The study involved 1150 people from the northern part of Lublin province (eastern Poland) at the age between15-20 years. The research tool applied was authors' own survey questionnaire.

Results. Over half of the surveyed young people $(58.9 \%)$ stated that they had been bitten by ticks before (mostly people who live in the rural areas). Most frequently, the ticks were removed by wringing with tweezers $(24.5 \%)$, grasping with fingers and tearing out $(21.7 \%)$ and with tweezers with a swift, steady movement (21.6\%). Over half of the surveyed (57.4\%) stated that they do not use repellents against ticks while staying on the green areas, and $33.2 \%$ of the surveyed rarely use them. $18.3 \%$ of the surveyed do not examine the body after the return from the green areas and $34.8 \%$ rarely do it. The surveyed who had been bitten by ticks (especially several times) claimed that they more often use the analysed methods of prevention.

Conclusions. Among the examined young people the risk of being bitten by ticks has been revealed and the risk is significantly greater among people who live in the rural areas. The ticks attached to skin were often removed improperly. The frequency of using the prevention against Lyme disease is insufficient. The increase of the range of its usage, as well as the promotion of the right method of removing ticks requires educational activities in the society.

Keywords: tick bites, Lyme borreliosis, prophylaxis

\section{Streszczenie}

Wprowadzenie. Kleszcze są głównym wektorem patogenów chorób zakaźnych zarówno ludzi, jak i zwierząt, a choroby odkleszczowe rozprzestrzeniają się obecnie w całej Europie. Wśród chorób szerzących się za pośrednictwem kleszczy dominuje borelioza z Lyme. Celem badań było określenie częstości ekspozycji na kleszcze badanej młodzieży, stosowanych sposobów jego usuwania oraz częstości stosowania wybranych metod profilaktyki boreliozy z Lyme.

Materiał i metody. Badaniem objęto 1150 osób z północnej części województwa lubelskiego (wschodnia Polska) w wieku 15-20 lat. Zastosowanym narzędziem badawczym był autorski kwestionariusz ankiety.

Wyniki. Ponad połowa badanej młodzieży (58,9\%) zadeklarowała, iż była w swoim życiu ukłuta przez kleszcza (częściej osoby zamieszkałe na wsi). Najczęściej kleszcze usuwano wykręcając je pęsetą $(24,5 \%)$, chwytając w palce i wyrywając $(21,7 \%)$ oraz usuwając pęsetą prostym, energicznym ruchem $(21,6 \%)$. Ponad połowa badanych $(57,4 \%)$ zadeklarowała, iż przebywając na terenach zielonych nie stosuje środków odstraszających kleszcze, a 33,2\% korzysta z nich rzadko. Nie ogląda ciała po powrocie z terenów zielonych 18,3\%, a 34,8\% robi to bardzo rzadko. Badani ukłuci w przeszłości przez kleszcza (szczególnie wielokrotnie), deklarowali częstsze stosowanie analizowanych sposobów profilaktyki.

Wnioski. Wśród badanej młodzieży wykazano narażenie na pokłucia przez kleszcze, istotnie częściej wśród osób mieszkających na wsi. Wkłute w skórę kleszcze często usuwane były w sposób nieprawidłowy. Częstość stosowania profilaktyki boreliozy z Lyme jest niewystarczająca. Zwiększenie zakresu jej stosowania, jak również promowanie prawidłowego sposobu usuwania kleszczy, wymaga działań edukacyjnych w społeczeństwie.

Słowa kluczowe: pokłucia przez kleszcze, borelioza z Lyme, profilaktyka

Panczuk A, Koziol-Montewka M. Exposure to ticks and preventive actions in the scope of Lyme disease among young people from the northern part of Lublin Province (Eastern Poland). Health Problems of Civilization. 2017; 11(1): 45-52. doi: 10.5114/hpc.2017.65522.

Address for correspondence / Adres korespondencyjny: Anna Pańczuk, Pope John Paul II State School of Higher Education, Sidorska 95/96, 21-500 Biała Podlaska, Poland, e-mail: anna.panczuk@poczta.onet.pl, phone +4883 3449900

Copyright: (C) 2017 Pope John Paul II State School of Higher Education in Biała Podlaska, Anna Pańczuk, Maria Kozioł-Montewka. This is an Open Access journal, all articles are distributed under the terms of the Creative Commons Attribution-NonCommercial-ShareAlike 4.0 International (CC BY-NC-SA 4.0) License (http:// creativecommons.org/licenses/by-nc-sa/4.0/), allowing third parties to copy and redistribute the material in any medium or format and to remix, transform, and build upon the material, provided the original work is properly cited and states its license. 


\section{Introduction}

In Europe, including Poland, ticks Ixodes ricinus are considered arthropods of the biggest epidemiological importance. The biological characteristics of I. ricinus, its big ecological adaptability, including the lack of the host's specific character allow for its widespread occurrence in the natural environment. In Poland the optimal habitats for I. ricinus occurrence are mixed forests with rich underbrush which provide the right humidity and which are characterised by the high concentration of hosts. Ticks are also quite numerous in deciduous forests with dense clusters of bushes, young trees and the undergrowth, as well as bushy brushwood and humid pastures [1]. The number of ticks is also significantly influenced by the presence of the lower flora, including bushes. Their removal significantly diminishes the number of ticks [2]. Within the studies of I. ricinus habitat preferences, which were conducted in the Lublin region, it was confirmed that the bigger populations of ticks appear in forests and their surrounding neighbourhood than in the open spaces. The biggest amount of ticks has been found in fresh pine woods, then in the mixed forests, as well as in young forest stands. In the open spaces, i.e. on the extensively used grasslands and pastures the occurrence of these saprophytes has been confirmed at a distance not exceeding $10 \mathrm{~m}$ from the forest wall. The optimal humidity in the period of ticks' activity has been pointed as the basic, decisive factor concerning their survival. Even not mown meadows and pastures can create more beneficial than deciduous forests conditions for the survival of those parasites [3]. More often the presence of I. ricinus is confirmed in urban and suburban areas, parks, squares, urban recreation areas, gardens, private properties and fallows [1] which increases the risk of being bitten by those arthropods. The warming of climate, which influences the model of human behaviour, also favours the risk of being bitten by ticks. These days human mobility is heightened; people spend more time in forests, gardens, parks, riding a bike; the popularity of active weekend leisure time has also increased [4].

The ticks are the main vector of pathogens of infectious diseases both for people and animals. At present, tickborne infections spread in the entire Europe [5]. Lyme disease, which is caused by bacteria Borrelia burgdorferi, dominates among diseases spreading through ticks. The prevalence of B. burgdorferi in ticks is the main factor when estimating the risk of contracting the Lyme disease in a given area. It gives a basis to acknowledge the examined area as an endemic area of that disease. The analysis of subject literature data which has been conducted by Rauer and Hartung, points out that in Europe the overall mean prevalence of Borrelia in ticks was 13.7\%. The prevalence widely oscillated depending on the analysed areas, as well as the applied research methods. The highest rates of infection of I. ricinus were found in countries in Central Europe (Austria, the Czech Republic, Southern Germany, Switzerland, Slovakia and Slovenia). Based on the analysed research, the authors rated Poland among the areas of low infectious status of ticks (nymphs 9.0\%, adult ticks 15.8\%) [6]. In the surveys of ticks from the Lublin region the infectious status oscillates between $5.4 \%$ [7] and $24.3 \%$ [8].

In Poland the number of registered Lyme diseases is systematically increasing. According to the initial data of the National Institute of Public Health - National Institute of Hygiene in the year 2015 were registered 13625 cases of diseased (incidence 35.4/100 000 inhabitants). The highest incidence rate, similarly as in the previous years, were registered in Podlasie province (96.3/100 000). In Lublin province the incidence rate reached 51.0/100 000 inhabitants [9].

The aim of the research was to determine the frequency of exposures on ticks of the subjected young people, applied ways of removing the ticks and the frequency of using the selected methods of Lyme disease prevention.

\section{Material and methods}

The study involved 1150 pupils of upper secondary schools from bialski poviat in northern part of Lublin province (eastern Poland). The respondents' age oscillated between 15 and 20 years (average age 17.2). The research tool was our own survey questionnaire. The questionnaire included 4 closed-ended questions, 1 halfopen question and a certificate. The questions concerned the frequency of staying on the green areas, the number of times of being bitten by ticks, the applied methods of removing ticks (half-open question), the frequency of using repellents and examining the body after the return from the areas of ticks' habitats. The certificate contained the questions about age, sex and place of residence (city, rural area and close to the forest / far from the forest).

Among the respondents women constituted $56.6 \%$ and men $43.4 \%$. In the study group there were more inhabitants from the rural area (63.7\%). The percentage of people who assessed that they live close to the forest was $49.6 \%$. In the study group the largest amount of people (42.9\%) stated that they often stay on the green areas, while $33.4 \%$ rarely do it.

In order to verify the hypothesises concerning the features' independence $\chi^{2}$ Pearson's test was conducted. For small numbers (below 5) in the study subgroup the Yeates' correction was applied. For big samples $\left(n_{1} \geq 100\right.$ and $\left.n_{2} \geq 100\right)$, in order to verify the hypotheses that structures' indicators (percentage) are in both populations the same, the significance 
test for both structures' indicators (percentage) was applied. For the statistical concluding 0.05 significance level was adapted. The statistical analyses were conducted based on the computer software STATISTICA v. 7.1 (StatSoft, Poland).

\section{Results}

Over half of the surveyed young people (58.9\%) stated that they had been bitten by a tick in their life. $15.9 \%$ of the respondents were bitten more than twice, $15.2 \%$ were bitten exactly two times, and $21.4 \%$ were bitten once. Part of people $(6.4 \%)$ could not determine the number of tick bites. The lack of knowledge concerning the possible tick bites was admitted by $5.0 \%$ of the respondents, whereas $36.1 \%$ stated that they had never been bitten. The final results are illustrated on Fig. 1 .

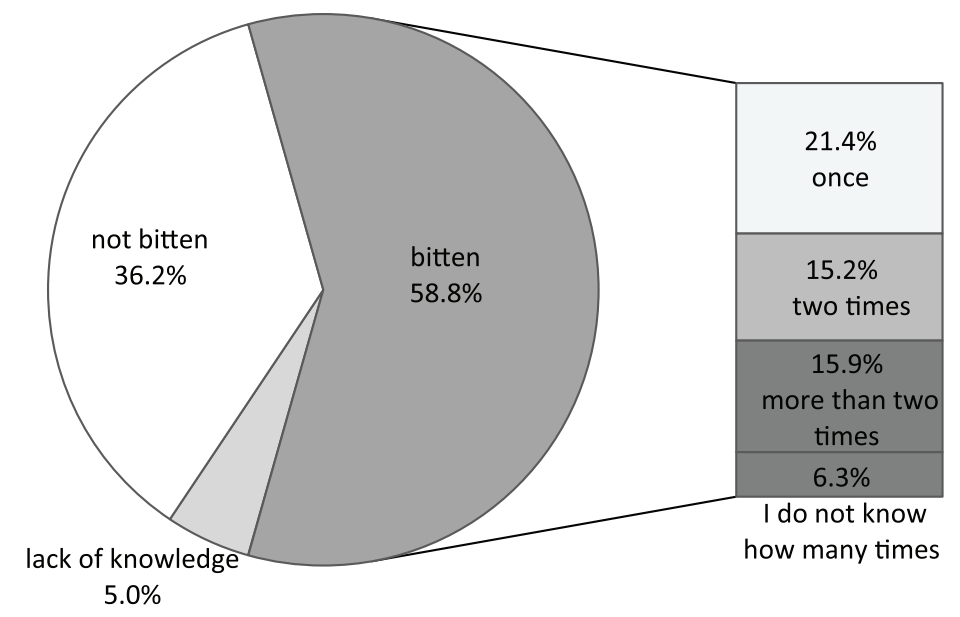

Figure 1. The number of times of being bitten by ticks

People living in the rural areas admitted of having been bitten by ticks substantially more often than people living in town $\left(\mathrm{p}<0.0001 ; \chi^{2}=32.78\right)$ (Fig. 2$)$.

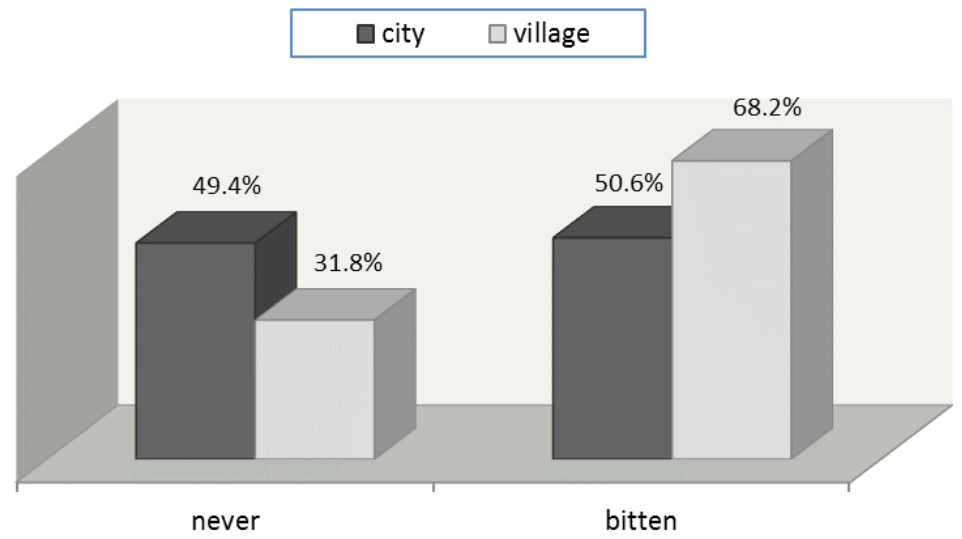

Figure 2. The occurrence of incidents of being bitten by ticks according to the place of residence $\left(\mathrm{N}=1092^{*}\right)$

* - the people who do not know if they were ever by ticks were not accounted for in the analysis

Statistically the significant correlation was found between the place of residence and the number of times of being bitten by ticks. Among the inhabitants of the rural areas the bigger percentage of people who were bitten once, two times and more than two times $\left(\mathrm{p}<0.0001 ; \chi^{2}=36.94\right)$ has been observed.

Among the people bitten by ticks $19.1 \%$ stated that it had been removed by a doctor or a nurse. Among the methods of removing a tick the most popular were: wringing with tweezers, (24.5\%), grasping with fingers and tearing out (21.7\%) and removing them with tweezers with a swift, steady movement (21.6\%). Putting on a greasy substance (e.g. a butter) in order to force the tick to leave by itself was admitted by $10.3 \%$ of the respondents. The remaining methods were less popular, and $32.4 \%$ of the respondents stated that they had disinfected the wound after the removal of a tick (Fig. 3). 


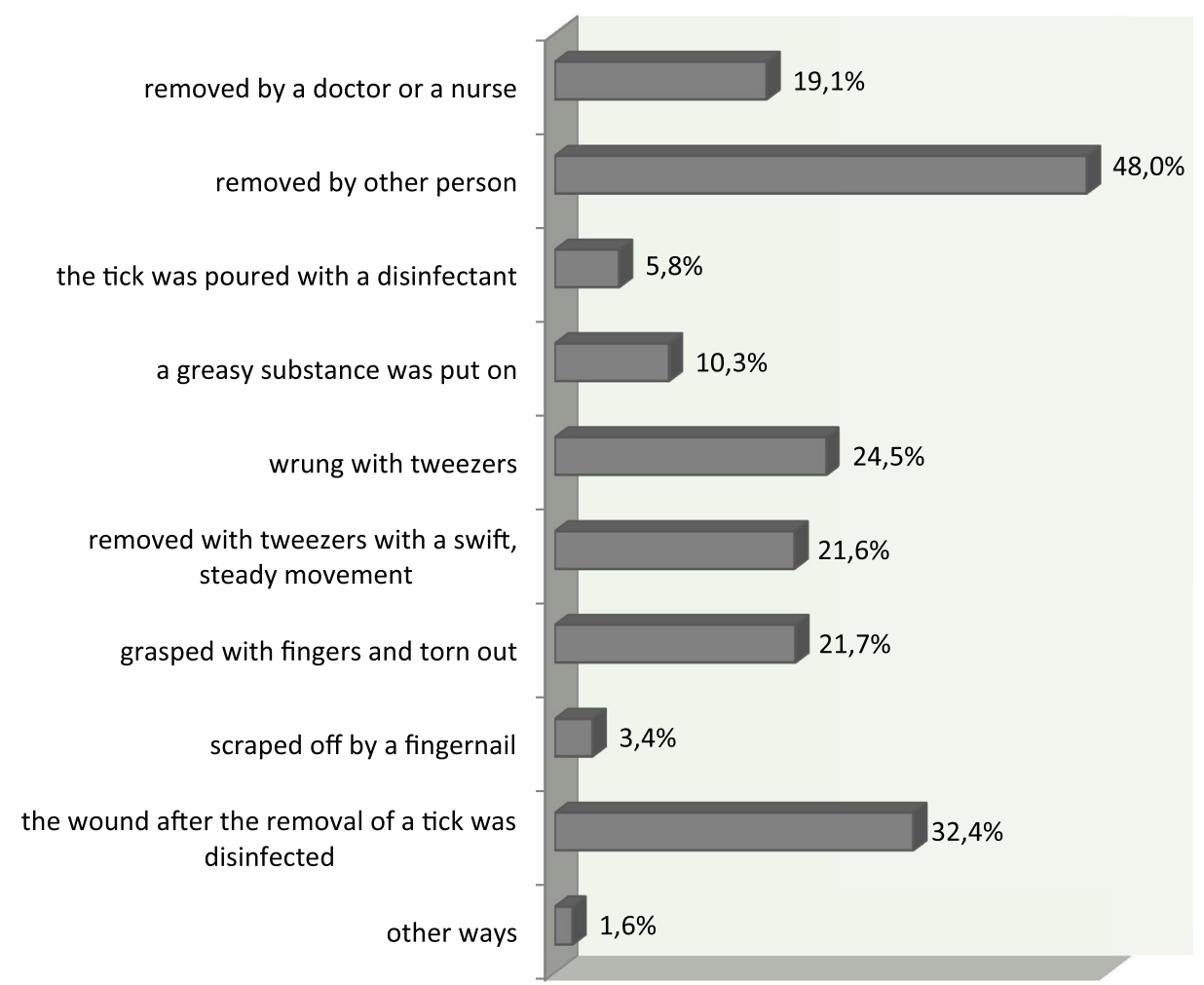

Figure 3. The applied methods of removing ticks among the bitten persons $\left(\mathrm{N}=677^{*}\right)$

* - the people who had not been bitten by a tick and people who had not known if they had been bitten were not accounted for in the analysis

The analyse of the place of residence has shown that young people coming from the rural areas more often used the right method of removing a tick $(\mathrm{p}=0.0004)$ and disinfected the wound after the removal of a tick $(\mathrm{p}=0.0008)$. Young people living in the cities more often removed a tick by putting on it a greasy substance $(p=0.0015)$.

Concerning the distance from the forest to the place of residence, it has been discovered that young people who live close to the forest were disinfecting the wound after the removal of a tick significantly more often than people who live a long way from the forest areas $(\mathrm{p}=0.0098)$. At the same time, however, members of that group applied wrong methods of removing the parasite like tearing out with fingers $(\mathrm{p}=0.0325)$ or pouring it with a disinfectant $(\mathrm{p}=0.0243)$.

More than half of respondents $(57.4 \%)$ declared that while staying in green areas, they do not use any tick repellents, and $33.2 \%$ use them rarely do (Fig. 4).

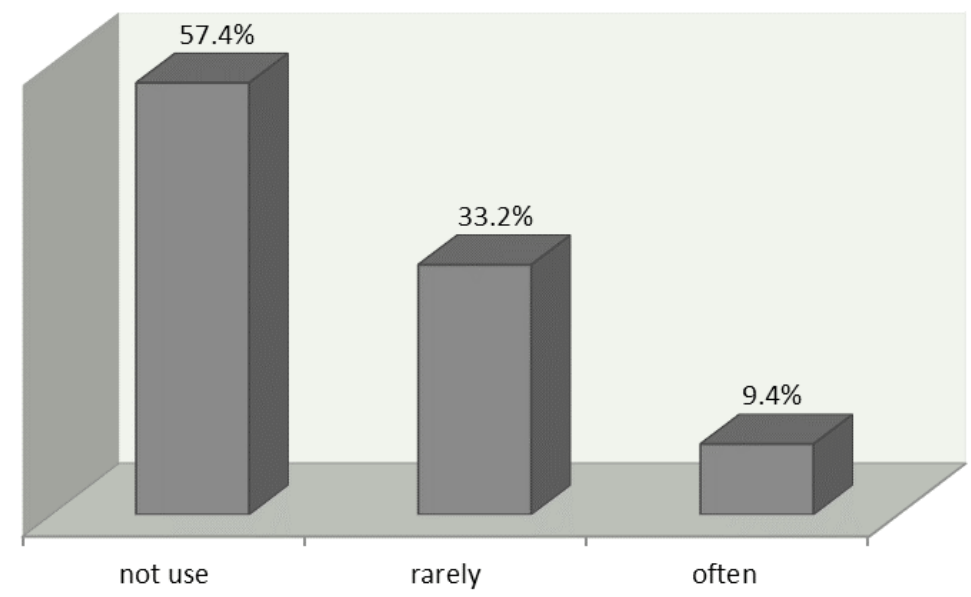

Figure 4. The frequency of tick repellents use

The relation between frequency of using the repellents, the place of residence and frequency of staying in green areas has not been detected. However, indeed, the person bitten by a tick in the past, declared the often use 
of repellents $\left(\mathrm{p}=0.0032 ; \chi^{2}=11.50\right)$. The relation between the frequency of using the repellents, and the number of bite episodes by these arthropods, has been detected $\left(\mathrm{p}=0.0147 ; \chi^{2}=19.04\right)$. People who were rarely bitten, while staying in green areas tend to apply repellents rarely. As the number of declared tick bite episodes increased, the percentage of people not using repellents decreased.

Apart from using the repellents, another element of Lyme disease prevention is to check the body carefully after returning from the green areas. Most people (34.8\%) declared that after returning from green areas, where they could have come into contact with ticks, they check their body very rarely (Fig. 5).

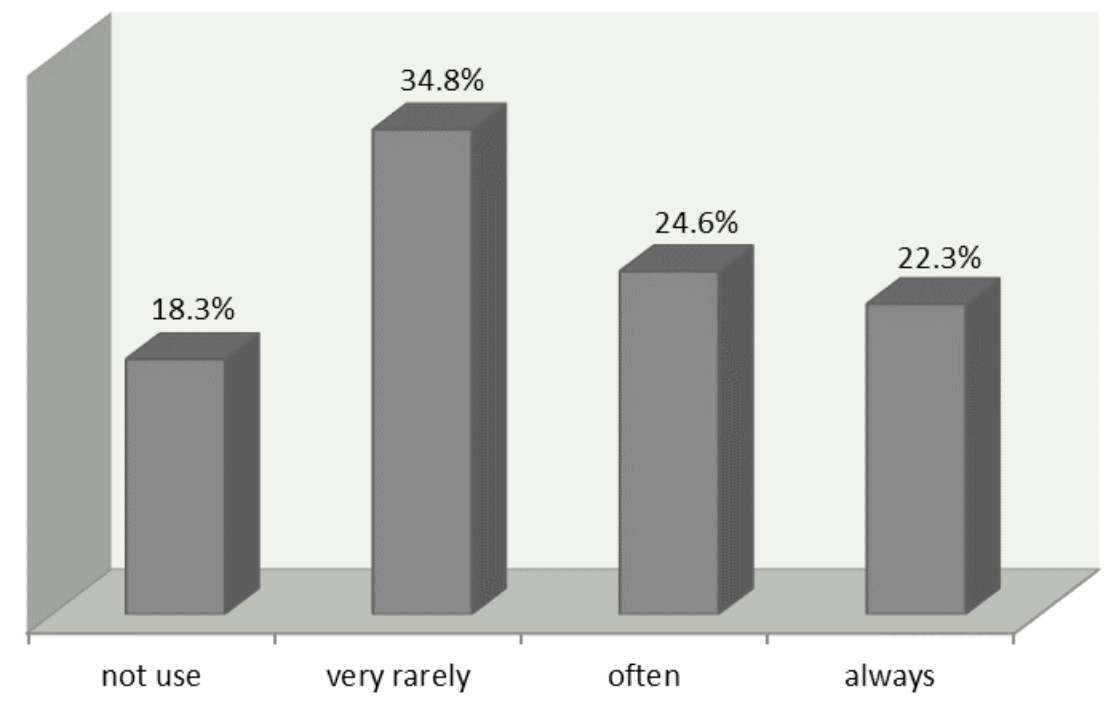

Figure 5. Frequency of body checking rule applied after returning from the green areas

The relation between frequency of body checking rule applied and place of residence has not been detected. People who spend more time in the green areas are more likely to remember about this form of prevention $(\mathrm{p}<0.0001$; $\left.\chi^{2}=39.30\right)$. A body checking rule is more likely to be declared by the people who have experienced a tick bite $(\mathrm{p}<0.0001$; $\left.\chi^{2}=31.63\right)$. Also, there is a relation ( $\left.p<0.0001 ; \chi^{2}=52.97\right)$ between the frequency of body checking rule being applied and the number of bite episodes by these arachnids. The highest percentage of those who always check their body after returning from the green areas was observed among those who were bitten more than two times (31.7\%).

Among the two analysed forms of Lyme disease prevention: using the repellents and body checking after returning from areas where ticks live, significantly higher percentage of the respondents $(p<0.0001)$ declared body checking rule being applied (Fig. 6).

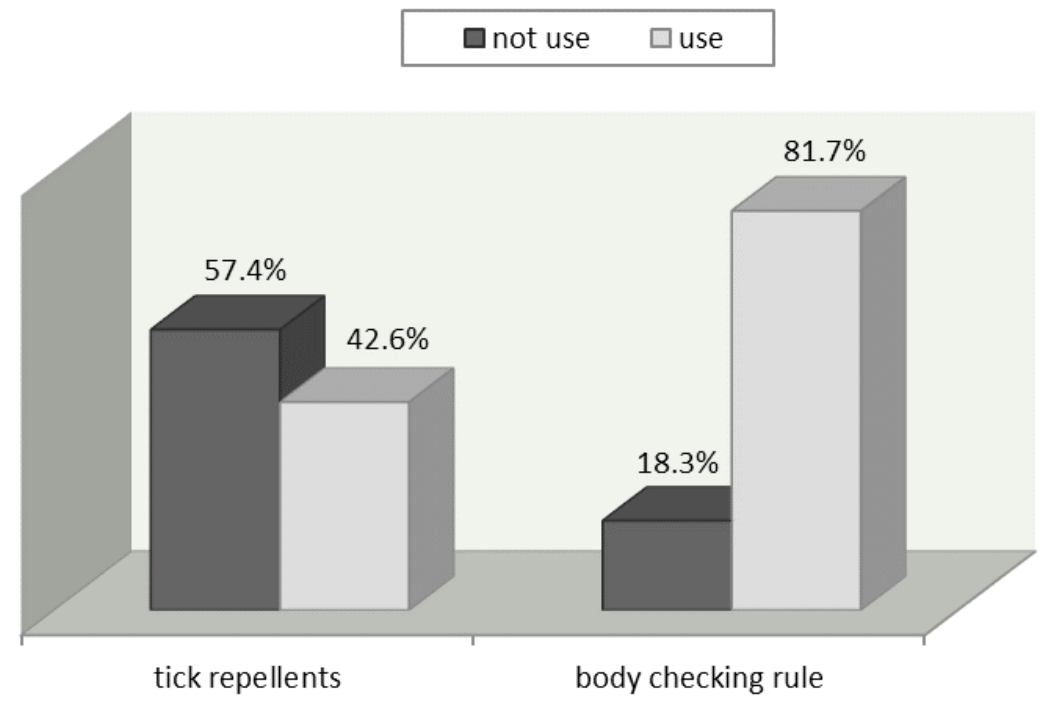

Figure 6. The use of tick repellents and a body checking rule 
The analysis conducted on the frequency of those two prevention forms detected an interaction $(\mathrm{p}<0.0001$; $\chi^{2}=147.44$ ) between the frequency of using the repellents, and the frequency of body checking rule. Along with the increasing frequency in using the repellents, the percentage of people declaring frequent and very frequent body checking rule being applied was growing.

\section{Discussion}

The northern part of Lublin province, where the tests were performed, has agricultural character and large afforestation. In addition, the area is known for dispersion forest clusters [10] and forest fragmentation associated with the length of forest edge and ecotones, all these factors have positive effect on the ticks density [11]. Despite the young age of the respondents, nearly $60 \%$ of them declared that they have been already bitten by ticks. A single tick bite episode was declared by $21.4 \%$, while, more than twice was declared by $15.9 \%$, it suggests a large exposure to ticks. Research conducted in Lublin region, showed that among those who are not occupationally exposed to ticks, the group of $26 \%$ of respondents declared the arthropod bite. Among those who occupationally belong to exposed group (foresters, farmers), the percentage was 66\% [12]. Paluchowska together with her colleagues conducted research among soldiers who serve in the northern-east of Poland. The tick bite before joining to military service was declared by $51.1 \%$ of soldiers. A single tick bite episode was declared by $26.6 \%$ of respondents, while $24.5 \%$ declared multiplied bites. In the controlled group which consisted of the soldiers from the military units located in non-endemic area, the occurrence of tick bites episode was declared by $23.4 \%$. A single tick bite episode was declared by $13.6 \%$, and multiplied by $9.8 \%$ [13]. In author's own research, the students who live in rural areas $(68.2 \%)$ are more likely to be bitten by tick, than students from urban areas (50.6\%). Especially big difference was observed among people who declared that they had been bitten more than twice. Among the students who live in rural areas, this group was represented by $20.0 \%$, while among urban population by $10.9 \%$. The northern part of Lublin province, where the tests were performed, is adjoining to the Podlasie province, where over the years the highest rates of Lyme disease incidence were observed [9]. An important element in the prevention of this disease is the correct and quick removal of the attached tick from skin. The use of incorrect ways of removing increases the pathogens transmission from the tick body to the skin. The most often recommended way is to grab it with tweezers, as close to the skin as possible and pull with straight, energetic movement perpendicular to the skin. After removing the tick, the skin should be disinfected $[14,15,16,17]$.

In author's research, respondents most often declared removing the tick by tweezers but with unscrewing move (24.5\%). A slightly smaller percentage of the young people (21.6\%) declared using the recommended method (using tweezers, a swift and steady move). Disinfection of the skin after removing the tick was declared by $32.4 \%$ of respondents. Young people from rural areas more often applied the correct way of removing and disinfected the skin, while those who live in cities declared removing the tick by covering it with oily substance.

In research conducted in the Lublin region by Bartosik, the most common way to remove a tick was plucking it with your fingers (44\%). Only $17 \%$ of respondents said they used the safest and recommended method for removing ticks with tweezers [12].

In research conducted by Deryło, as many as $74 \%$ of patients hospitalized with Lyme disease, knew the proper method for ticks removing, and ensured that they followed this method in practice. Ticks were not removed at all, or removed incorrectly by "scraping" in case of $17.1 \%$ of respondents [18].

Because of the absence of specific methods of Lyme disease prevention, involving the administration of the vaccine and /or immunoglobulins, the most effective method of prevention is to avoid exposure to ticks [19]. It is recommended to avoid places of possible contact with ticks, wear clothing which would protect as much skin as possible (long sleeves and legs) and prevent getting a tick under the clothes (tight-fitting cuffs, long legs put in socks) $[4,14,20,21,22]$. Due to the seasonal activity of ticks attributable to the period from spring to autumn, thus the period when high temperature is recorded, this method is likely to be used in practice. An important element in Lyme disease prevention is to remove the attached tick as soon as possible because the longer the infected tick feeds itself, the higher the risk for infection $[15,16,17,18,22,23]$. It seems that, the body checking rule is even more important in this case and guarantees fast removal of this parasite. Another recommended way to prevent Lyme disease is to use the repellents over the skin and / or clothing $[14,16,17,19,21,22]$.

In our research, more than half of young people (57.4\%) stated that they do not use tick repellents. The prevention, involving the body checking, is not used by $18.3 \%$ respondents, while $34.8 \%$ used it rarely. The positive seems to be the fact that $22.3 \%$ always use it. People who used the repellents more often, also followed the body checking rule.

The relation between the frequency of following the analysed prevention methods and the place where the respondents live was not detected. However, indeed, the usage rate of these methods was higher among those who experienced tick bite in the past. In this group, however, still more than half (53.2\%) declared that they do not use the repellents, and $23.4 \%$ did not check the body after returning from the green areas. Simultaneously, it was observed 
that as the number of bite episodes was increasing, the percentage of people not using tick repellents was decreasing. Therefore, it must be believed, that the previous experience increases the level of Lyme disease prevention.

Also, other research indicate that awareness among inhabitants of the Lublin region in the field of prevention methods is low $[12,18,25]$. In research conducted in the Lublin region by Bartosik together with his colleagues, $38 \%$ of respondents declared using repellents, while protection by wearing right clothing was declared by $35 \%$ of them. The use of repellents was more often declared by people who live in urban area (45\%) than those who live in rural one (22\%). On the other hand, the aftermost were more willing to wear the right clothing (49\%) than foremost (28\%). A rule of body checking after returning from the areas of tick occurrence was declared by $43 \%$ of the respondents, and not using any form of prevention was declared by $21 \%$ [12].

Among the group of patients in Biłgoraj who visited a doctor in order to remove the tick, more than half (53\%) declared knowledge and following the basic rules of prevention for tick-borne diseases. A detailed analysis on forms of prevention showed that in fact, the prevention is used by a small percentage of people. The most often declared form of prevention, was wearing proper clothing (26\%). The use of repellents was declared by $13 \%$ of respondents, and checking the clothes after leaving the forest and other possibly tick-infested areas was only declared by $4 \%$ [25].

In Deryło's research, up to 60\% of patients from the Lublin province, hospitalized with Lyme disease never used any of the available prevention methods, and in most of the cases this was due to their ignorance. The author noted the worrying fact that the remaining part of this large group deliberately did not follow any forms of prevention. Among the $40 \%$ of patients who declared that they used the methods of prevention, more than half in situations of exposure to tick tried to apply all the security rules (wearing right clothing and checking it after returning home, using the repellents, early and proper tick remove). The others declared following only selected methods of prevention, while most common was wearing right clothing. Less educated people were less likely to follow any preventive rules, largely due to their ignorance or lack of knowledge. Among the patients who work in forestry as many as $90 \%$ of respondents declared total use of prevention methods. At the same time, in case of the farmers, who are the second most exposed to ticks group, they were not familiar with the methods of Lyme disease prevention [18]. The basic knowledge of the epidemiology and tick-borne diseases prevention among employees of forest exploitation was proved by Cisak together with his colleagues. Among this group, 92\% declared checking their body after returning from the forest areas. The use of repellents over the body was declared by $76 \%$ and $59 \%$ over clothing [26].

A wide range of educational materials on Lyme disease prevention is available on Centers for Disease Control and Prevention website [17]. There is no information on Lyme disease prevention in the most recent recommendations issued in 2015 by Polish Society of Epidemiology and Infectious Diseases concerning the diagnosis and treatment of diseases transmitted by ticks [27]. Brief information was mentioned in the earliest recommendations published in 2008, [20] and 2011 [28].

The research shows that the majority of respondents had already experienced a tick bite. At the same time, the frequency of following the methods of Lyme disease prevention declared does not appear to be sufficient. Due to this reason, greater efforts are needed to promote tick-borne diseases prevention and spreading knowledge about ticks. The practice of incorrect tick removing increases the risk of a possible infection with B. burgdorferi spirochetes, therefore, it is extremely important to include the elements of demonstration on how to safely remove this parasite into prevention. This requires further and more effective cooperation between the State Sanitary Inspection and medical personnel in the area of public education regarding non-standard methods on how to prevent infections.

\section{Conclusions}

1. Among the examined young people the risk of being bitten by ticks has been revealed and the risk is significantly greater among people who live in the rural areas.

2. The ticks attached to skin were often removed improperly.

3. The frequency of Lyme disease prevention is inadequate. In order to increase the level of knowledge among society, as well as promote the correct way of removing ticks educational activities in the community are required.

\section{References:}

1. Kiewra D. Evaluation of the vector role of ticks Ixodes ricinus L. 1758 (Acari, Ixodidae) in the transmission of Borrelia burgdorferi s.l. in Poland, with a particular focus on the Lower Silesia. Wrocław: I-Bis; 2014 (in Polish).

2. Tack W, Madder M, Baeten L, Vanhellemont M, Verheyen K. Shrub clearing adversely affects the abundance of Ixodes ricinus ticks. Exp Appl Acarol. 2013; 60(3): 411-420.

3. Biaduń W. Habitat preferences of the common tick Ixodes ricinus L. in Lublin region. Wiad Parazytologiczne 2008; 54(2): 117-122 (in Polish). 
4. Zajkowska J. Tick bite a risk of tick-borne encephalitis. How to avoid bites and illness. Forum Zakażeń 2015; 6(2): 127-133 (in Polish).

5. Hai VV, Almeras L, Socolovschi C, Raoult D, Parola P, Pagès F. Monitoring human tick-borne disease risk and tick bite exposure in Europe: available tools and promising future methods. Ticks Tick Borne Dis. 2014 Oct;5(6): 607-619. doi: 10.1016/j.ttbdis.2014.07.022.

6. Rauter C, Hartung T. Prevalence of Borrelia burgdorferi Sensu Lato Genospecies in Ixodes ricinus Ticks in Europe: a Metaanalysis. Appl Environ Microbiol. 2005; 71(11): 7203-7216.

7. Cisak E, Chmielewska-Badora J, Wójcik-Fatla A, Zwoliński J. Badania w kierunku Borrelia burgdorferi, Anaplasma phagocytophilum, Babesia microti i wirusa kleszczowego zapalenia mózgu w kleszczach z terenów Lubelszczyzny. Przegl Epidemiol. 2008; 62(supl.): 170 (in Polish).

8. Wójcik-Fatla A, Zając V, Cisak E, Sroka J, Sawczyn A, Dutkiewicz J. Leptospirosis as a tick-borne disease? Detection of Leptospira spp. in Ixodes ricinus ticks in eastern Poland. Ann Agric Environ Med. 2012; 19(4): 656-659.

9. http://www.pzh.gov.pl/ [cited 2016 June 24]

10. Województwo lubelskie. Podregiony, powiaty, gminy 2015. Urząd Statystyczny w Lublinie, 2015 (in Polish).

11. Li S, Heman P, Cochez C, Simons L, Vanwambeke SO. A multi-level analysis of the relationship between environmental factors and questing Ixodes ricinus dynamics in Belgium. Parasit Vectors. 2012; 25(5): 149. doi: 10.1186/1756-3305-5-149.

12. Bartosik K, Kubrak T, Olszewski T, Jung M, Buczek A. Prevention of tick bites and protection against tick-borne diseases in south-eastern Poland. Ann Agric Environ Med. 2008; 15(2): 181-185.

13. Paluchowska E, Czarnecka I, Walory J, Zabielski S, Malewicz J, Samochocki Z, et al. Występowanie przeciwciał przeciwko Borrelia burgdorferi wśród żołnierzy odbywających służbę w północno-wschodniej Polsce. Lekarz Wojskowy 2001; 77(1): 12-15 (in Polish).

14. Grzeszczuk A. Borelioza w praktyce klinicznej. Warszawa: PZWL; 2009 (in Polish).

15. Zajkowska J. Borelioza z Lyme - standardy leczenia a oczekiwania chorych. Przegl Epidemiol. 2008; 62(supl.): 142-151 (in Polish) .

16. Rizzoli A, Hauffe HC, Carpi G, Vourc’h GI, Neteler M, Rosŕ R. Lyme borreliosis in Europe. Eurosurveillance 2011; 16(27): 2-9.

17. https://www.cdc.gov/Lyme [cited 2016 Jul 01]

18. Deryło J. Epidemiologia boreliozy z Lyme w województwie lubelskim w latach 2000-2004. Praca doktorska. Akademia Medyczna w Lublinie 2007 (in Polish).

19. Stanek G, Wormser GP, Gray J, Strle F. Lyme borreliosis. Lancet. 2012; 379: 461-473.

20. Flisiak R, Pancewicz S. Diagnostyka i leczenie Boreliozy z Lyme rekomendacje Polskiego Towarzystwa Epidemiologów i Lekarzy Chorób Zakaźnych. Przegl Epidemiol. 2008; 62: 193-199 (in Polish).

21. Wormser GP, Dattwyler RJ, Shapiro ED, Halperin JJ, Steere AC, Klempner MS, et al. The Clinical Assessment, Treatment, and Prevention of Lyme Disease, Human Granulocytic Anaplasmosis, and Babesiosis: Clinical Practice Guidelines by the Infectious Diseases Society of America. Clinical Infectious Diseases. 2006; 43: 1089-1134.

22. Krzyczmanik D, Sińczuk-Walczak H, Wittczak T, Cyran A, Pałczyński C, Walusiak-Skorupa J. Borreliosis in occupational medicine practice. Med Pr. 2012; 63(4): 483-492 (in Polish).

23. Steere AC, Coburn J, Glickstein L. The emergence of Lyme disease. The Journal of Clinical Investigation. 2004; 113(8): 1093-1101.

24. Hathaway LR. Lyme disease. Nursing. 2005; 35(4): 44-45.

25. Bartosik K, Kubrak T, Sitarz M, Święcicka M, Buczek A. The public health risk of ticks and tick-borne diseases in the south-eastern Poland. Wiad Parazytol. 2004; 50(2): 249-252 (in Polish).

26. Cisak E, Zwoliński J, Chmielewska-Badora J, Dutkiewicz J, Wójcik-Fatla A, Zając V. Analysis of the state of knowledge and awareness in the area of tick-borne diseases prophylaxis in the population at occupational risk. Zdr Publ. 2011; 121(1): 47-51.

27. Pancewicz SA, Garlicki AM, Moniuszko-Malinowska A, Zajkowska J, Kondrusik M, Grygorczuk S, et al. Diagnosis and treatment of tick-borne diseases recommendations of The Polish Society of Epidemiology and Infectious Diseases. Przegl Epidemiol. 2015; 69: 309-316.

28. Flisak R, Pancewicz S. Diagnostyka i leczenie Boreliozy z Lyme. Zalecenia Polskiego Towarzystwa Epidemiologów i Lekarzy Chorób Zakaźnych - 2011. [cited 2015 Jul 15]. Available from: http://www.pteilchz.org.pl/data/ standardy/borelioza_z_lyme_2011.pdf 